\title{
THE PROXIMATE ANALYSIS AND SPECTRAL PROFILE OF CHITIN EXTRACTED FROM THE SHELL OF Portunus pelagicus ORIGINATED FROM CIREBON, INDONESIA
}

\author{
R. Amelia ${ }^{1,2}$, I. Indawati ${ }^{1}$, N. M. Saptarini ${ }^{3}$, J. Levita ${ }^{2, 凶}$ and S. A. Sumiwi ${ }^{2}$ \\ ${ }^{1}$ Department of Pharmacology, School of Pharmacy Muhammadiyah Cirebon, \\ Cirebon-45153, (West Java) Indonesia \\ ${ }^{2}$ Department of Pharmacology and Clinical Pharmacy, Universitas Padjadjaran, \\ Sumedang-45363, (West Java) Indonesia \\ ${ }^{3}$ Department of Pharmaceutical Analysis and Medicinal Chemistry, Universitas Padjadjaran, \\ Sumedang-45363, (West Java) Indonesia \\ ${ }^{\square}$ Corresponding Author: jutti.levita@unpad.ac.id
}

\begin{abstract}
Indonesia has a great potential to be exploited for its abundant marine resources, e.g. the blue swimming crab (Portunus pelagicus). During 2018 in West Java, P. pelagicus is highly utilized (8.423,89 tons or 5.127\% of the total production throughout Indonesia). However, the shell waste (approximately $40-60 \%$ of the total crab weight) is usually deserted and needs to be further exploited. In this work, we extracted chitin from P. pelagicus shells originated from Cirebon-West Java, Indonesia, using the natural deep eutectic solvents (NADES): a mixture of choline chloride and malic acid. The extraction was carried out twice using the same solvents. The chitin produced, by employing NADES, was proximate-analyzed and UV/IR spectrophotometric-characterized. The two times-extraction of chitin from $P$. pelagicus shells using NADES yielded chitin powder of $35.43 \% \mathrm{w} / \mathrm{w}$. The proximate analysis indicates that our chitin meets the Indonesian National Standard requirements, and its infra-red spectrum confirms the $\beta$-chitin form. It could be concluded that chitin extracted from the wasted shell of $P$. pelagicus possesses a good quality, very low level of arsenic and lead, and therefore could be further developed as active pharmaceutical ingredients.

Keywords: chitin, chitosan, choline chloride, malic acid, NADES solvents, Portunus pelagicus
\end{abstract}

RASĀYAN J. Chem., Vol. 14, No.3, 2021

\section{INTRODUCTION}

Indonesia, possessing an immense marine area, has a great potential to be exploited for its abundant natural resources, e.g. the blue swimming crab (Portunus pelagicus). The native habitat of this particular crab is the Western Indo-Pacific. A cluster analysis revealed two stock units of P. pelagicus in the Indonesian fisheries management area, the first stock was Southern Madura, and the other stocks were East Lampung, Lancang Island, Cirebon, and Rembang. ${ }^{1}$ In Indonesia, especially West Java, P. pelagicus is highly utilized. Its utilization in 2018 reached $8.423,89$ tons or $5.127 \%$ of the total production throughout Indonesia. However, the shell waste (approximately $40-60 \%$ of the total crab weight) is deserted and needs to be further exploited. ${ }^{2}$

Interestingly, this neglected crab shell contains chitin. Chitin has been widely used in agriculture as an insecticide. Moreover, pharmaceutical fields such as biomedical food wound dressings also contain chitin. Chitin and/or its deacylated product, chitosan, is used in the textile industry, to efficiently protects yarns during weaving. ${ }^{3,45}$ Factors affecting the yield and character of chitin are harvesting seasons, ${ }^{6}$ extraction methods, ${ }^{7}$ and sources used in the manufacture of chitin. ${ }^{8,9}$

In this work, we extracted chitin from P. pelagicus shells originated from Cirebon-West Java, Indonesia, using the natural deep eutectic solvents (NADES), a solvent synthesized from natural ingredients, that is environment-friendly. ${ }^{10}$ Furthermore, the proximate content and heavy metals level in the produced-chitin were also analyzed. 
RASĀYAN J. Chem.

Vol. 14 | No. 3 |1755-1760| July - September | 2021

\section{Instruments}

\section{EXPERIMENTAL}

Rewez multifunctional microwave oven EM820ABT, 80-1 tabletop low speed electric medical centrifuge (Jiangsu Jinyi Instrument Technology Company Limited, China), inductively coupled plasma-optical emission spectrometer (ICP-OES) (ThermoScientific iCAP PRO Series), Fourier-Transform infrared spectrophotometer (ThermoScientific, Nicolet 380), UV-visible spectrophotometry (Shimadzu UV mini1240).

\section{Materials and Chemicals}

The blue swimming crab shell (P. pelagicus), Ø 13-15cm originated from Gunung Jati Cirebon, West Java, Indonesia, choline chloride CAS No. 67-48-1 (Salus Nutra Inc), DL-malic acid (Salus Nutra Inc), commercial chitin produced from crustacean (Carbosynth) used as the standard, potassium bromide analytical grade (Merck), hydrochloric acid 37\% analytical grade (Merck), distilled water.

\section{Preparation of NADES}

NADES was prepared by following the method of Huang and colleagues (2018) $)^{11}$, i.e. mixing a 1: 1 molar ratio of choline chloride and DL-malic acid. The mixture was heated to $80^{\circ} \mathrm{C}$ with constant stirring until a homogeneous liquid was formed.

\section{Extraction of Chitin}

The blue swimming crab shell powder (mesh-60) was mixed with NADES (1:20) to a homogenous mixture. The mixture was heated in the microwave at $700 \mathrm{w}$ for $9 \mathrm{~min}$, during which it was taken out from the microwave every minute for $3 \mathrm{sec}$ to avoid overheating. Chitin, formed as a precipitate, and NADES were separated by centrifugation. ${ }^{11}$ The obtained chitin was washed with distilled water and re-extracted using the same procedure. The product was named REC (re-extracted chitin).

\section{Proximate Analysis}

Proximate content (moisture, ash, protein, fat, and carbohydrate) in the P. pelagicus shell powder, the commercial chitin, and REC, was strictly determined according to the protocol of the Indonesian National Standard SNI 01-2891-1992. ${ }^{12}$

\section{Determination of Heavy Metals}

Approximately $0.5 \mathrm{~g}$ of the sample was dissolved with heating in $5 \mathrm{~mL}$ of $\mathrm{HNO}_{3}$, cooled to room temperature, and filtered. The solution was diluted with Milli-Q water in a $25 \mathrm{~mL}$ volumetric flask.

The standard metal solutions and the sample were measured using inductive couple plasma-OES (ICPOES) at the maximum wavelength of each metal, i.e. As $188.9 \mathrm{~nm}$; Ca $396.9 \mathrm{~nm}$; Cd $226.5 \mathrm{~nm}$; Co 238.9 nm; Cr 283.6 nm; Cu 327.4 nm; Fe 238.2 nm; Hg 253.6 nm; K 766.5 nm; Mg 279.5 nm; Mn 257.6 nm; Na $588.9 \mathrm{~nm} ; \mathrm{Pb} 220.4 \mathrm{~nm}$; Sn 283.9 nm. ${ }^{13}$

\section{Qualitative UV-Spectrophotometric Analysis}

$10 \mathrm{mg}$ of standard chitin and the sample in a separate flask were dissolved in $4.2 \mathrm{~mL}$ of $\mathrm{HCl} 37 \%$. The solutions were immediately diluted with distilled water to get a concentration of $80 \mathrm{ppm}$. Measurement was carried out at $200-250 \mathrm{~nm}$.

\section{FTIR-Spectrophotometric Analysis}

$1 \mathrm{mg}$ of previously dried chitin was dispersed in approximately $200 \mathrm{mg}$ of potassium bromide $(\mathrm{KBr})$ and was pressurized under vacuum for $10 \mathrm{~min}$ to form pellets. The pellets were analysed using an infrared spectrophotometer at a frequency of $4000-500 \mathrm{~cm}^{-1} \cdot{ }^{14}$

\section{RESULTS AND DISCUSSION}

The demineralization process in the extraction of chitin is conventionally carried out using strong mineral acids $\left(\mathrm{HCl}, \mathrm{HNO}_{3}, \mathrm{H}_{2} \mathrm{SO}_{4}\right)$, organic acids $\left(\mathrm{CH}_{3} \mathrm{COOH}\right.$ and $\left.\mathrm{HCOOH}\right)$, however, dilute $\mathrm{HCl}$ is the most often 
chosen solvent. Moreover, deproteination generally employs alkalines (sodium hydroxide, potassium hydroxide, calcium hydroxide) and salts $\left(\mathrm{Na}_{2} \mathrm{CO}_{3}, \mathrm{NaHCO}_{3}, \mathrm{~K}_{2} \mathrm{CO}_{3}\right) .{ }^{15}$ However, the waste (solvent residue) could damage the environment, e.g. the severe impacts of alkaline residues on aquatic environments. ${ }^{16}$

Meanwhile, the natural deep eutectic solvent (NADES) is known as a sustainable, non-toxic, and biodegradable solvent. NADES has been developed for extracting superior quality chitin from crustacean shells. ${ }^{11}$ Considering these advantages, NADES was chosen as the solvent in our work for chitin extraction (two times) from the blue swimming crab (P. pelagicus) shells and resulted in a fine dry powder (Fig.-1b) compared to the commercial standard chitin (Fig.-1a).

A mixture of choline chloride and DL-malic acid (NADES) has been reported to successfully extract superior quality chitin from shrimp shells. ${ }^{11}$ Choline chloride can remove protein from the shells, while DLmalic acid was able to demineralize calcium carbonate compounds from the crustacean shells. This can be seen from the decomposition of calcium carbonate that dissolves in water by releasing carbon dioxide bubbles. ${ }^{17}$ The demineralization process produces salts that dissolve easily, washing with deionized water is carried out to separate salt and solids. ${ }^{15}$

Our two times-extraction of chitin from the blue swimming crab (P. pelagicus) shells using choline chloride and DL-malic acid yielded more chitin powder $(35.43 \% w / w)$ (Fig.-1b) compared to that of chitin produced by using $1 \mathrm{~N} \mathrm{HCl}$ and $1 \mathrm{~N} \mathrm{NaOH}(20.24 \%)$ extracted from Malaysian P. pelagicus. ${ }^{18}$
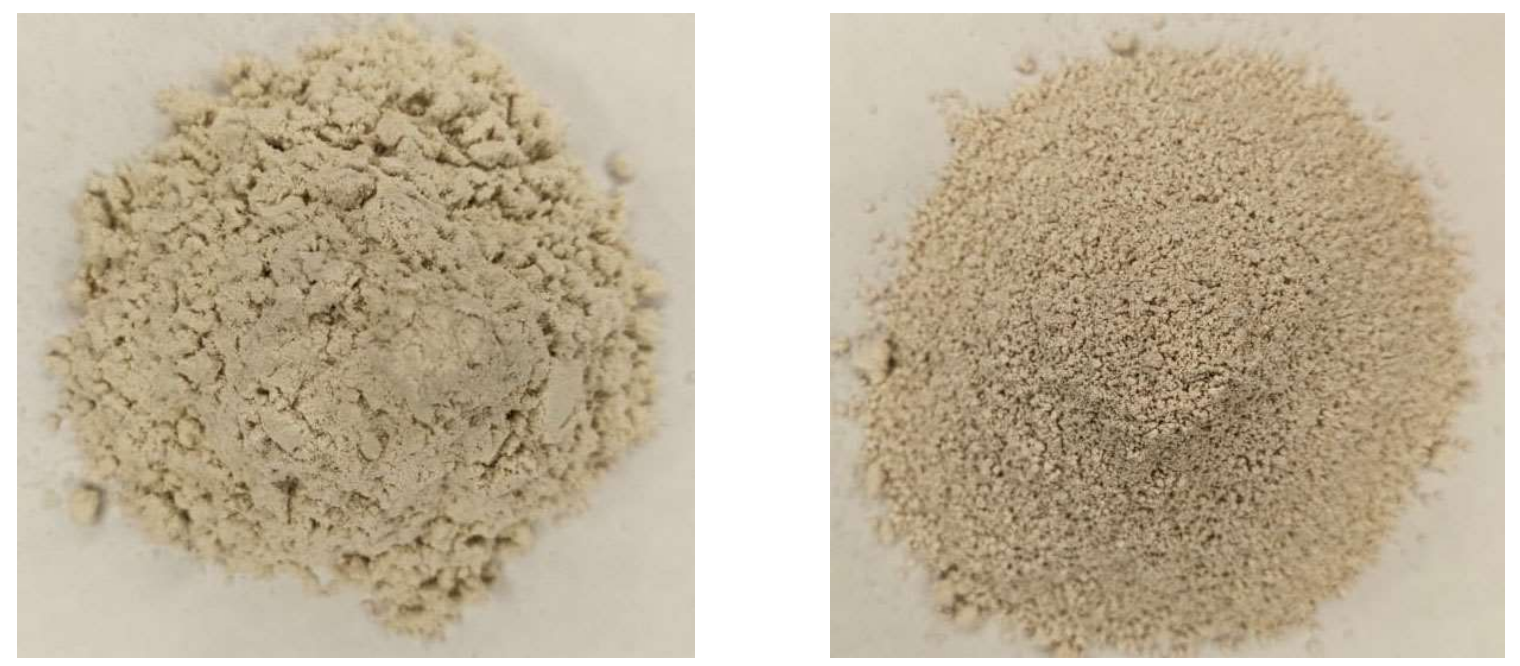

Fig.-1: The Powder of (a) Commercial Standard Chitin and (b) REC (Re-extracted Chitin) from P. pelagicus) Shells

\section{Proximate Content}

$($ Yield $=35.43 \% w / w)$.

The proximate content (protein, moisture, ash, fat, and carbohydrate) in the $P$. pelagicus shell powder, the commercial chitin, and REC is provided in Table-1.

Table-1: Proximate Content in the P. pelagicus Shell Powder, the Commercial Chitin, and REC

\begin{tabular}{c|c|c|c}
\hline Proximate Content & P. pelagicus Shell Powder (\%) & Commercial Chitin (\%) & REC (\%) \\
\hline Moisture & 4.53 & $5.70 \pm 0.0$ & $1.93 \pm 1.5$ \\
\hline Ash & 71.31 & $1.97 \pm 0.1$ & $30.61 \pm 8.6$ \\
\hline Protein & 8.17 & $0.39 \pm 0.2$ & $0.30 \pm 0.0$ \\
\hline Fat & 0.26 & $16.83 \pm 20.2$ & $12.50 \pm 8.8$ \\
\hline Carbohydrate & 15.73 & $75.12 \pm 20.3$ & $54.67 \pm 1.7$ \\
\hline
\end{tabular}

According to the Indonesian National Standard, ${ }^{12}$ the maximum percentage of water and ash content is $12 \%$ and 5\%, respectively. However, the ash contained in REC from P. pelagicus shells was still high (Table1). Our result was in agreement with that of Toliba and co-workers ${ }^{19}$ who reported that the ash content in 
the blue swimming crab sample was higher (71.3\%) than that of the crustacean shell from Egypt (33-38\%). ${ }^{19}$ High ash content indicates that the demineralization process has not been completed. ${ }^{9,20}$

The protein content in REC $(0.30 \%)$ resembled commercial chitin $(0.39 \%)$. Moreover, although REC contains high carbohydrates $(54.67 \%)$, it is less amount than that of the commercial chitin $(75.12 \%)$. High protein content indicates the presence of organic and nitrogenous substances, ${ }^{9}$ which often trigger allergies in humans. ${ }^{15}$ Whereas high carbohydrate content is not surprising, because originally chitin is a polysaccharide composed of $\mathrm{N}$-acetyl-2-amino-2-deoxyglucose units linked by $\beta-(1 \rightarrow 4)$ bonds. $^{21}$

\section{Heavy Metals Content}

Chitin can absorb toxic metal ions such as $\mathrm{Cd}, \mathrm{Ni}, \mathrm{Cu}, \mathrm{Pb}$, and $\mathrm{Zn},{ }^{22}$ however, it is important to determine the heavy metal content in chitin to ensure its safety and quality The result is presented in Table- 2 .

Table-2: Heavy Metals Content in Chitin

\begin{tabular}{c|c|c}
\hline Heavy Metal & Commercial Chitin $(\mathrm{mg} / \mathrm{kg})$ & REC $(\mathrm{mg} / \mathrm{kg})$ \\
\hline $\mathrm{As}$ & $<0.0001 \pm 1.40$ & $<0.0001 \pm 2.67$ \\
\hline $\mathrm{B}$ & $<0.0001 \pm 0.01$ & $<0.0001 \pm 0.01$ \\
\hline $\mathrm{Ca}$ & $1736.4114 \pm 0.02$ & $1861.0928 \pm 0.00$ \\
\hline $\mathrm{Cd}$ & $<0.0001 \pm 0.00$ & $<0.0001 \pm 0.03$ \\
\hline $\mathrm{Co}$ & $<0.0001 \pm 0.06$ & $1.4471 \pm 0.06$ \\
\hline $\mathrm{Cr}$ & $4.1262 \pm 0.00$ & $<0.0001 \pm 0.05$ \\
\hline $\mathrm{Cu}$ & $2.4251 \pm 0.02$ & $466.1976 \pm 0.12$ \\
\hline $\mathrm{Fe}$ & $89.2382 \pm 0.02$ & $<0.0001 \pm 0.02$ \\
\hline $\mathrm{K}$ & $<0.0001 \pm 0.00$ & $438.4930 \pm 0.02$ \\
\hline $\mathrm{Mg}$ & $1120.1151 \pm 0.06$ & $29.1966 \pm 0.00$ \\
\hline $\mathrm{Mn}$ & $28.7790 \pm 0.01$ & $369.1667 \pm 0.07$ \\
\hline $\mathrm{Na}$ & $300.9026 \pm 0.05$ & $<0.0001 \pm 0.04$ \\
\hline $\mathrm{Pb}$ & $7.4737 \pm 0.24$ & $17.7944 \pm 0.09$ \\
\hline $\mathrm{Sn}$ & $5.9413 \pm 0.04$ & $<0.0001 \pm 0.01$ \\
\hline $\mathrm{Hg}$ & $9.6613 \pm 0.05$ &
\end{tabular}

The maximum level of As and $\mathrm{Pb}$ in chitin is $5 \mathrm{mg} / \mathrm{kg} .{ }^{12}$ Both REC and the commercial chitin meet this requirement. Moreover, the amounts of $\mathrm{Cu}, \mathrm{Pb}$, and $\mathrm{Hg}$ in $\mathrm{REC}$ were smaller than the commercial chitin (Table-2). These results have proven that NADES solvent was suitable for obtaining a good quality of chitin.

The ionic character of NADES, obtained from the complexation of hydrogen acceptor compounds (e.g. choline chloride) and hydrogen bond donor compounds (e.g. malic acid), is capable of extracting heavy metals in young barley with the efficiency percentage of $\mathrm{Mn}(26 \%), \mathrm{Cu}(8 \%), \mathrm{Zn}(24 \%), \mathrm{Mo}(52 \%){ }^{22} \mathrm{The}$ mechanism that may play a role in reducing the concentration of heavy metals in chitin is ion exchange. Choline chloride which is an alkaline compound acts as an anion exchanger, while malic acid is a cationexchanger. ${ }^{23}$

\section{Qualitative UV-Spectrophotometric Analysis}

The UV-spectrophotometric analysis indicates that $\lambda \max 208.5 \mathrm{~nm}$ is for commercial chitin and $\lambda$ max $206.5 \mathrm{~nm}$ is for REC (depicted in Fig.-2).

An acetonitrile extract of chitin, recorded in the UV spectral region 196-248 nm, was reported showing a maximum at $212.6 \mathrm{~nm}$. This band was caused by the $\mathrm{n}-\pi^{*}$ electronic transition type due to the secondary amide fragment of chitin. ${ }^{26}$

\section{FTIR-Spectrophotometric Analysis}

Figure- 3 depicts the infrared spectrum of the chitin recorded in the spectrum field $4000-500 \mathrm{~cm}^{-1}$ in the form of $\%$ transmittance ( $y$-axis) versus wavenumber ( $x$-axis).

Fig.-3 depicts the bands of C-O aliphatic $\left(1,100 \mathrm{~cm}^{-1}\right) ; \mathrm{C}-\mathrm{N}$ stretch $\left(1380 \mathrm{~cm}^{-1}\right) ; \mathrm{C}=\mathrm{O}$ stretch $\left(1600 \mathrm{~cm}^{-1}\right)$; the amide's carbonyl $\left(1660 \mathrm{~cm}^{-1}\right)$; C-H alkyl (2890-2968 $\left.\mathrm{cm}^{-1}\right)$; and O-H alcohol $\left(3400-3550 \mathrm{~cm}^{-1}\right)$, which 
are similar for both chitins. The band at $2900 \mathrm{~cm}^{-1}$ is usually used as a reference band in identifying chitin. ${ }^{25}$ The part of spectra that confirms $\alpha$-chitin is the presence of the amide's carbonyl $(-\mathrm{C}=\mathrm{O})$ band at 1660 and $1620 \mathrm{~cm}^{-1}$ and the amide's secondary amine $(-\mathrm{N}-\mathrm{H})$ at $1552 \mathrm{~cm}^{-1}$. These two sharp peaks at 1660 and 1620 $\mathrm{cm}^{-1}$ are not found in $\beta$-chitin. ${ }^{26,27}$ Commercial chitin, extracted from Crustaceans, confirms the $\alpha$-chitin form. Interestingly, the spectrum of REC from $P$. pelagicus indicates the $\beta$-chitin form.

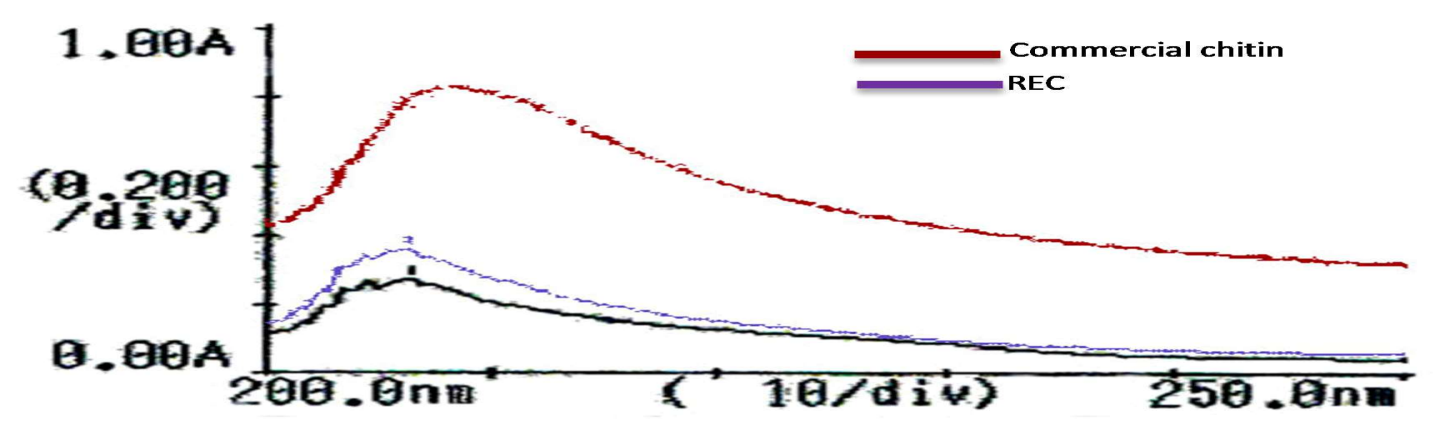

Fig.-2: UV Spectra of Commercial Chitin (Red Spectrum; $\lambda$ max $208.5 \mathrm{~nm}$ ) and REC (Blue and Black Spectra; $\lambda$
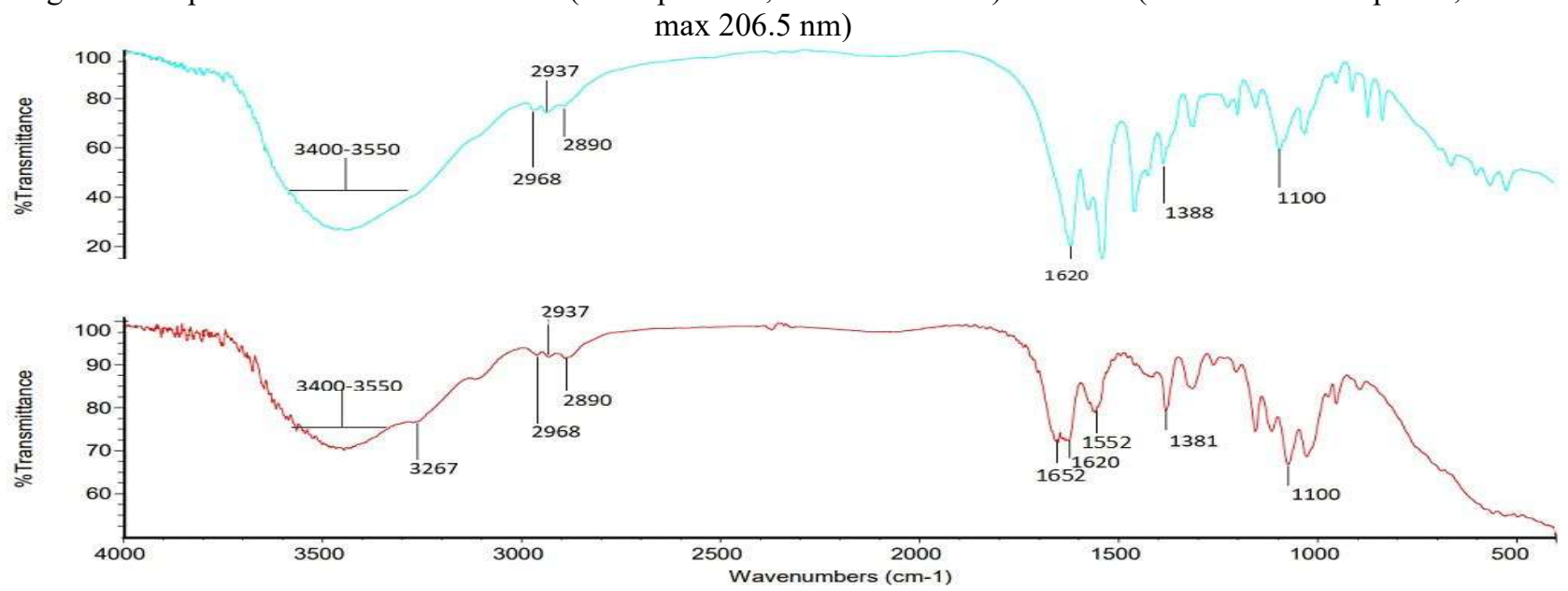

Fig.-3: FTIR Spectra of Commercial Chitin (Red) and REC (Blue)

\section{CONCLUSION}

Extraction of chitin from the blue swimming crab (Portunus pelagicus) shells, originated from West Java, Indonesia, using NADES (choline chloride: malic acid) solvent, has produced a good quality of $\beta$-chitin. This chitin reveals low moisture, protein, and fat content, however, high carbohydrate, and ash are quantified. The extracted chitin meets the requirement of heavy metals content following the Indonesian National Standard.

\section{ACKNOWLEDGEMENT}

The authors would like to thank the Rector of Universitas Padjadjaran (West Java, Indonesia) for funding the publication fee via the Directorate of Research and Community Engagement. The present work was conducted in the framework of the doctoral dissertation of the first author at the Faculty of Pharmacy, Universitas Padjadjaran, West Java, Indonesia.

\section{REFERENCES}

1. N. Afifah, Z. Zairion, H. H. Maduppa, A. A. Hakim and Y. Wardiatno, Journal of Natural Resources and Environmental Management, 10(3), 390(2020), https://doi.org/10.29244/jpsl.10.3.390-401

2. E. Rochima, Kajian Pemanfaatan Limbah Rajungan dan Aplikasinya untuk Bahan Minuman Kesehatan Berbasis Kitosan (2015), http://pustaka.unpad.ac.id/wp-content/uploads/2015/10/KAJIANPEMANFAATAN-LIMBAH-RAJUNGAN-DAN-APLIKASINYA.pdf

3. T. Hahn, L. Bossog, T. Hager, W. Wunderlich, R. Breier, T. Stegmaier and S. Zibek, 2019, Chitosan Application in Textile Processing and Fabric Coating, in: L.A.M. van den Broek and C.G. Boeriu 
RASĀYAN J. Chem.

Vol. 14 | No. 3 |1755-1760| July - September | 2021

(Eds.), Chitin and Chitosan: Properties and Applications, John Wiley \& Sons Ltd, https://doi.org/10.1002/9781119450467.ch16

4. I. Aranaz, M. Mengíbar, R. Harris, I. Paños, B. Miralles, N. Acosta, G. Galed and Á. Heras, Current Chemical Biology, 3, 203(2009), https://doi.org/10.2174/2212796810903020203

5. J.C. Roy, F. Salaün, S. Giraud and A. Ferri, 2017, Solubility of Chitin: Solvents, Solution Behaviors and Their Related Mechanisms. In Solubility of Polysaccharides, in: Z. Xu (Ed.), Solubility of Polysaccharides, InTechOpen, https://doi.org/10.5772/intechopen.71385

6. D. Ayas, Journal of Marine Biology \& Oceanography, 02(02), 16(2013), https://doi.org/10.4172/2324$\underline{8661.1000110}$

7. R. Amelia, N. M. Saptarini, J. Levita, S. A. Sumiwi, Journal of Applied Pharmaceutical Science, 10(12), 140(2020), https://doi.org/10.7324/JAPS.2020.101218

8. E. B. Ibitoye, I. H. Lokman, M. N. M. Hezmee, Y. M. Goh, A. B. Z. Zuki and A. A. Jimoh, Biomedical Materials (Bristol), 13(2), 1(2018), https://doi.org/10.1088/1748-605X/aa9dde

9. M. T. Isa, A. O. Ameh, J. O. Gabriel and K. K. Adama, Leonardo Electronic Journal of Practices and Technologies, 11(21), 73(2012).

10. L. Benvenutti, A. A. F. Zielinski and S. R. S. Ferreira, Trends in Food Science and Technology, 90, 133(2019), https://doi.org/10.1016/j.tifs.2019.06.003

11. W. C. Huang, D. Zhao, N. Guo, C. Xue and X. Mao, Journal of Agricultural and Food Chemistry, 66(45), 11897(2018), https://doi.org/10.1021/acs.jafc.8b03847

12. Indonesian National Standard SNI 01-2891-1992. Uji Makanan dan Minuman. Badan Standardisasi Nasional (BSN), Jakarta.

13. I. Hoxha, N. Shala and G. Q. Xhabiri, Rasayan Journal of Chemistry, 11(2), 682(2018), https://doi.org/10.7324/RJC.2018.1123024

14. H. Darmokoesomo, F.R. Setianingsih, T. W. L. C. Putranto, H. S. Kusuma, Rasayan Journal of Chemistry, 9(4), 550(2016).

15. I. Younes and M. Rinaudo, Marine Drugs, 13, 1133(2015), https://doi.org/10.3390/md13031133

16. H. I. Gomes, W. M. Mayes, M. Rogerson, D. I. Stewart and I. T. Burke, Journal of Cleaner Production, 112(4), 3571(2016), https://doi.org/10.1016/j.jclepro.2015.09.111

17. E. J. Dompeipen, Majalah BIAM, 13(1), 31(2017).

18. N. M. Ahyat, F. Mohamad, A. Ahmad and A. A. Azmi, Malaysian Journal of Analytical Sciences, 21, 770(2017), https://doi.org/10.17576/mjas-2017-2104-02

19. A. O. Toliba, M. A. Rabie and G. M. El-Araby, Zagazig Journal of Agricultural Research, 41(5), 1067(2014).

20. Y. L. Ni'mah, H. Harmami, I. Ulfin, S. Suprapto and C. W. Saleh, Malaysian Journal of Fundamental and Applied Sciences, 15(2), 159(2019), https://doi.org/10.11113/mjfas.v15n2.971

21. A. Lopez-Santamarina, A. del Carmen Mondragon, A. Lamas, J. M. Miranda, C. M. Franco and A. Cepeda, Foods, 9(6), 782(2020), https://doi.org/10.3390/foods9060782

22. N. Osowska and L. Ruzik, Food Analytical Methods, 12(4), 926(2019), https://doi.org/10.1007/s12161018-01426-y

23. A. Dąbrowski, Z. Hubicki, P. Podkościelny and E. Robens, Chemosphere, 56(2), 91(2004), https://doi.org/10.1016/j.chemosphere.2004.03.006

24. P. Negrea, A. Caunii, I. Sarac and M. Butnariu, Digest Journal of Nanomaterials and Biostructures, 10(4), 1129(2015).

25. N. Jothi and R. K. Nachiyar, Global Journal of Biotechnology and Biochemistry, 8(1), 1(2013), https://doi.org/10.5829/idosi.gjbb.2013.8.2.1107

26. M. Kaya, M. Mujtaba, H. Ehrlich, A. M. Salaberria, T. Baran, C. T. Amemiya, R. Galli, L. Akyuz, I. $\begin{array}{lllll}\text { Sargin, J. Labidi, } & \text { Carbohydrate }\end{array}$ https://doi.org/10.1016/j.carbpol.2017.08.076

27. X. Feás, M. P. Vázquez-Tato, J. A. Seijas, A. P. G. Nikalje and F. Fraga-López, Molecules, 25(2), (2020), https://doi.org/10.3390/molecules25020384

[RJC-6354/2021] 